\title{
Who speaks for extinct nations? The Beothuk and narrative voice
}

\author{
Carl Leggo' \\ Department of Language Education \\ University of British Columbia \\ Vancouver, British Columbia \\ CANADA
}

\begin{abstract}
The Beothuk of Newfoundland were among the first inhabitants of North America to encounter European explorers and settlers. By the first part of the nineteenth century the Beothuk were extinct, exterminated by the fishers and soldiers and settlers of western Europe. The last Beothuk was a woman named Shanadithit. She was captured and lived with white settlers for a few years before she died in 1829. Today all that remains of the Beothuk nation, which once numbered seven hundred to one thousand people, are some bones, arrowheads, tools, written records of explorers and settlers, and copies of drawings by Shanadithit in the Newfoundland Museum.

In recent years several writers (all are white and male) have written fiction and poetry and drama about the Beothuk, including Peter Such (Riverrun, 1973), Paul O'Neill (Legends of a Lost Tribe, 1976), Sid Stephen (Beothuk Poems, 1976), Al Pittman ("Shanadithit," 1978), Geoffrey Ursell (The Running of the Deer: A Play, 1981), Donald Gale (Sooshewan: A Child of the Beothuk, 1988), and Kevin Major (Blood Red Ochre, 1990). A recurring theme in all these narratives is the theme of regret and guilt. These narrative accounts of the Beothuk raise significant questions about voice and narrative, including: Who can speak for Native peoples? Who can speak for extinct peoples? Are there peoples without voices? How is voice historically determined? What is the relationship between voice and power? How are the effects of voice generated? What is an authentic voice? How is voice related to the illusion of presence? What is the relation between voice and silence?
\end{abstract}

See p. 181-183 of Litera for poems written by Carl Leggo. (From the collection of poems Growing up perpendicular on the side of a hill - 1994.) 
In examining contemporary narrative accounts of the Beothuk my goal is to reveal the rhetorical ways in which the Beothuk are given voice(s) and to interrogate the ethical and pedagogical implications of contemporary authors revisiting and revisioning and re-voicing a nation of people long extinct.

\section{Introduction}

The Beothuk ${ }^{2}$ of Newfoundland were among the first inhabitants of North America to encounter European explorers and settlers. At the end of the fifteenth century British and French explorers learned about the abundant natural resources of fish available in the Atlantic Ocean off the coast of Newfoundland. For the next four centuries the British and the French sought to secure a hold on this lucrative fishing industry by engaging in political and military conflicts with each other as well as with the Beothuk who had lived on the island of Newfoundland for many centuries before the Europeans came. By the first part of the nineteenth century the Beothuk were extinct, exterminated by the fishers and soldiers and settlers of Western Europe. Sometimes the Beothuk were killed like animals for the sport of killing. In some cases they were perceived as a threat to the safety of the fishers and were attacked. Some Beothuk died after contracting diseases like smallpox and tuberculosis from the white settlers. Even when the political leaders of the colony of Newfoundland attempted to help the Beothuk, the schemes backfired. In one case a decree was issued that a reward would be paid to anyone who captured and delivered a Beothuk to the British governor of the colony. The plan was to teach the captured Beothuk the English language and explain to him or her that the white settlers wanted to live in peace with the Beothuk. Then the captured Beothuk would be returned to his or her people as an ambassador who could speak favourably about the white settlers. Unfortunately the plan was not clearly understood, and some people assumed that the offer of the reward was for the delivery of a Beothuk, dead or alive. As a consequence of this political scheme many more Beothuk died.

The last Beothuk was a woman named Shanadithit. She was captured and lived with white settlers for a few years before she died in 1829 . It is unlikely that she ever knew she was the last of her people. Today all that remains of the Beothuk nation, which once numbered seven hundred to one thousand people (Marshall, 1989:36), are some bones, arrowheads, tools, written records of explorers and settlers, and copies of drawings by Shanadithit in the Newfoundland Museum.

The words Beorhuk and Shanandithit are occasionally spelled in different ways in this essay because authors use different spellings and when I cite an author I use his or her spelling 
Little is known about the Beothuk. In the spring and summer they lived on the northwest coast of Newfoundland where they fished and hunted seals and seabirds. Then in the autumn they migrated inland and camped near the head-waters of the river that would one day be named the Exploits River. They spent winters trapping fur-bearing animals. They were, according to reports, a tall and handsome people, known for their peacefulness and ingenuity for living in the harsh and rugged climate and landscape of Newfoundland. The early explorers who reached North America thought they had in fact reached India and called the Beothuk Indians. And because the Beothuk rubbed red ochre into their skin, probably as a protection against mosquitoes, they were called Red Indians. They knew themselves as the Beothuk which means 'the People.'

In recent years several writers (all are white and male) have written fiction and poetry and drama about the Beothuk, including Peter Such (Riverrun, 1973), Paul O'Neill (Legends of a Lost Tribe, 1976), Sid Stephen (Beothuk Poems, 1976), Al Pittman ("Shanadithit," 1978), Geoffrey Ursell (The Running of the Deer: A Play, 1981), Donald Gale (Sooshewan: A Child of the Beothuk, 1988) and Kevin Major (Blood Red Ochre, 1990). A recurring theme in all these narratives is the theme of regret and guilt, expressed by Al Pittman in the following excerpts from his poem "Shanadithit":

\section{Shanadithit}

What I know of you is only

what my grade seven history book

told me.

That you were young when they caught you.

That your people lived in deerhide houses.

That they changed your name to Nancy.

That you died soon after.

That you were the last of the Beothuks.

And when you died your lonely death, when the white disease put an end to you, you didn't know that all these years

beyond your decay I would long to be with you, to tell you

I wouldn't forget.

Lie easy in your uneasy peace girl

and do not, do not, forgive those

who trespass against you. (43-46)

These narrative accounts of the Beothuk raise significant questions about voice and narrative, including: Who can speak for Native peoples? Who can speak for 
extinct peoples? Are there peoples without voices? How is voice historically determined? What is the relationship between voice and power? How are the effects of voice generated? What is an authentic voice? How is voice related to the illusion of presence? What is the relation between voice and silence?

In examining contemporary narrative accounts of the Beothuk my goal is to reveal the rhetorical ways in which the Beothuk are given voice(s) and to interrogate the ethical and pedagogical implications of contemporary authors revisiting and revisioning and re-voicing a nation of people long extinct.

\section{2. (In)appropriate appropriation of voice(s)}

To continue appropriating our stories and misusing them in the name of 'freedom of imagination' is just so much racism. My old typewriter and I sit in my bedroom where the magic of Trickster lives. We object to the theft of our stories and the distortion of our lives. (Maracle, 1990a:186.)

To continue telling Native stories, writing Native stories, is to continue speaking for Native people and paraphrasing Native people - censoring the Native voice. And for what, the sake of the great white imagination, an imagination that kills Natives softly with white metaphors and poetry, and trivializes Native gods? (Keeshig-Tobias, 1990:174.)

The danger with writers carrying their unfettered imaginations into another culture - particularly one like the Native Canadian culture which theirs has oppressed and exploited - is that without careful thought, they are likely to perpetuate stereotypical and one-dimensional views of this culture. (Philip, 1990:215.)

We do as Native writers suffer because of the kind of cultural imperialism that's taking place when non-Native people speak about Native ceremony and Native thinking, Native thought, Native life style, Native world view and speak as though they know what they are speaking about. That's appropriation of culture... . (Armstrong, 1990a:50.)

Is appropriation always inappropriate? The etymology of appropriate acknowledges contradiction. As a verb appropriate means 'to take for one's own or exclusive use; hence, to steal;' as an adjective appropriate means 'suitable, fit, proper'. Appropriate/appropriate suggests that stealing is suitable and proper. There is a dilemma about whether appropriating is appropriate, and not surprisingly the dilemma is re/presented in the etymology of the word.

More questions: Can I appropriate the voice of an/other? Is this even possible? Am I not always awash in the sea of voices, interjecting my multiple voices among the multiple voices of others, trying on different voices? Is the appro- 
priation of voice a kind of theft like stealing a person's soul by photographing the person? Is the appropriation of voice a rhetorical dis/guise (grant it replete with lots of political and ethical and moral ramifications as rhetoric always entails)?

When I write I write from the locus of my embodied subject positions - man, white, Newfoundlander, heterosexual, father, husband, poet, university educated, working-class upbringing, middle-aged. My voice(s) sing from the locus of these identifying and naming and constraining and informing subject positions. I am not seeking to steal or usurp or supplant an/other's opportunities to speak/write in her/his voice(s). But I know that the issues are knotted with complex threads.

The problem of appropriation in Canadian literature is a hotly contested issue that generated wide public interest and awareness during the 1988 Third International Feminist Book Fair in Montreal, Quebec when Lee Maracle - who is a Canadian Native writer - asked Anne Cameron - who is a Canadian white writer - to stop using Native stories in her books. A lively debate in the Writer's Union of Canada concerning issues of appropriation and censorship and freedom of imagination has continued unabated since the climactic event of Maracle's request to Cameron. The problem of appropriation of voice is energetically debated in the literary and academic journals of Canada as well as in the popular press where writers like Rudy Wiebe and W.P. Kinsella hurl off letters to the editor filled with criticism for each other's attitudes concerning the issue of appropriation of Native stories. And the issue extends beyond the issue of Native writing and writers. Because Canada is a country with an official government policy of multiculturalism as a mosaic of diversity, there is at least a bureaucratic commitment to celebrating the voices of the many peoples who constitute the people of Canada: those who lived in the country before colonization and during colonization, as well as those who have immigrated, and continue to immigrate to the country in this century. In other words, Canada has a history of colonization and immigration as well as a literary history of seeking to learn to live with the consequences and repercussions of the history of colonization and immigration.

Writers in Canada are seeking ways to listen to one another, and to acknowledge and honour the differences that characterize the people of Canada. When Lee Maracle asked Anne Cameron to stop including the stories of Native people in her books, a loud debate ensued concerning questions about freedom of speech and censorship and ownership of language and freedom of imagination. But Cameron (1990:68) has rebutted charges of censorship: "I have not been censored or stifled, or denied any freedom of speech or expression; I have been asked to take a step or two to one side. Not down. To one side." As Maracle (1990a: 182) explains, "There is a controversy in the realm of fiction writing in Canada. A good many Native writers across Canada have been objecting of late to the appropriation of our stories by Canadian writers". But Maracle adds that the con- 
troversy is not about censoring the freedom of writers' imaginations. From the perspective of Native peoples in Canada Maracle (1990a:186) contends that "the fact is that a white person appropriating our stories because they lack imagination or knowledge of their own is still telling a European story". She adds: "Use whatever you like to ground your story, intellectual Canada, but be honest. It is your story - it is not about me."

The theoretical and critical debates about appropriating the stories of colonized and marginalized peoples in Canadian writing show no signs of diminishing interest or currency. Successive issues of Essays on Canadian Writing, Studies in Canadian Literature, and Canadian Literature include lengthy essays on the issues of appropriation. The literary history of Canada is one of change. In terms of post-colonial theory Canada was a settler colony in which invading settlers from Europe, mostly the British Isles and France, claimed the land and resources which had been enjoyed by indigenous peoples. The first European settlers who arrived in Canada from Great Britain and France brought with them the literary texts and practices of their countries. The indigenous peoples of Canada were increasingly marginalized by a system of reservations where they lived as wards of the government. Then new immigrants to Canada brought their diverse literary traditions and practices, thereby helping to create Canada as a site where issues of post-colonial and multicultural identity and literature and language are being discussed with passionate and scholarly attention - a discussion that is integrally connected to Canada's continuing existence as a nation where diversity does not have to be feared but can be celebrated.

In reflecting on the debate which erupted at the 1988 Third International Feminist Book Fair in Montreal when Lee Maracle asked Anne Cameron to stop using Native narratives in her books, Daphne Marlatt (1990:16), a white Canadian writer, notes that "the extent of our ignorance" about difference is "still scandalous news". I agree with Marlatt that the ignorance of difference is a scandal, a cause for stumbling, but I also note that the knowledge of difference is a scandal, a cause for stumbling. As I read narratives about the Beothuk, I am unsettled, I stumble with the scandal. I have many questions: Who has the right to tell stories? Who tells stories? Who owns stories? Whose stories are told? How are the stories told? What stories are told? Who decides what stories are told? Who decides who will tell the stories? Why are the stories told? Where are the stories told? When are the stories told? Is a story always a scandal? Do stories always cause us to stumble by preventing our easy passage through reality, our wistful blindness and deafness to the ruptures, the differences, the dissonances, the gaps, the other and alternative realities that interrupt the seeming seamlessness of our apparently real lived experiences? Marlatt refers to "that definite unease you feel when the ground of your sense of the real" and "the edifice of values we live inside of" are shaken (Marlatt, 1990:18). 
Laurie A. Finke (1992:4) interrogates "language, representation, history, culture, and difference", as she argues for "a theory of complexity" which "reveals the messiness behind the illusion of unified narratives about the world by restoring information" - what she calls noise - "previously marginalized and excluded by those narratives" (Finke, 1992:7, 8). According to Finke (1992:8) a theory of complexity "attempts to expose the 'ficticity' - or the constructed nature - of facts". She promotes a Bakhtinian dialogic and double-voiced exploration of social and cultural phenomena (Finke, 1992:11). If I write a narrative about the Beothuk I write in certain voices and I constrain the voices in the text, but I do not entirely control the text or the operations of voices in the text; I do not control the voices that readers construct in the text because the text is open for multiple uses, plural responses, a heteroglossic babel of voices. The linear and logical and monotheistic and teleological and unitary narratives that have been propagated to construct and line the universe through the eyes of white men are just so many stories designed to conceal the messiness of complexity. When I write a narrative I hear not only my own voices calling out to you, calling back to me, one more desperate and echoic gabfest to fend off the darkness, but other voices that sing in the air, voices that do not acknowledge the fiction of chronological time, voices that do not acknowledge their silence, voices that speak out of noise and dreams and difference and visions and memory. Even though no Beothuk lives to write the stories of her people, other writers writing about the Beothuk provide opportunities for the voices of the Beothuk to be heard. For Finke (1992:19) who objects to "tidy narratives of discovery", history "resides in the essential tension between 'what really happened' and the multiple and shifting narratives about it" (Finke, 1992:23). She rejects as inadequate "linear representations of historical narrative" (Finke, 1992:24). She wants to "go beyond straightforward notions of 'authenticity,' 'voice,' and 'experience' - all of which postulate the author as the transcendental signified of her text" (Finke, 1992:99-100) in order to acknowledge "the dialogic cultural activity that structures the writing of any text" (Finke, 1992:100). Voice is a literary construct, a heteroglossic site of subjectivitymaking. There is "no single unified 'voice,' but a babel of contradictory and conflicting cultural signs" (Finke, 1992:104-105). The notion of an authentic voice is based on realist and essentialist epistemologies that erase the constructedness of plural and contested and dialogic subjectivities.

And, therefore, the master narratives which are pronounced and propagated as providing foundational and fundamental truths for understanding the lived experiences of human beings are only more partial narratives since narratives are always partial. The white, middle class, educated, male writers currently telling stories about the Beothuk are the descendants of the people who exterminated the Beothuk. They know almost nothing about them. In the beginning the white European colonizers could not understand the Beothuk or refused to understand 
them, and out of greed, fear, and cruelty killed them. Now the descendants of those white European men are seeking to understand the Beothuk, but the only words they have to help them construct their stories are the words of white European men who recorded a little of their history among the Beothuk or interviewed the last Beothuk and acted as scribes or translators for her words. The stories of the Beothuk are always mediated through the words of white European men. The Beothuk did not write. They sang their stories. And the stories they sang have been lost with them. The only extant graphic records composed by the Beothuk are the drawings of Shanandithit. As Lee Maracle (1991a:186) notes, "the fact is that a white person appropriating our stories because they lack imagination or knowledge of their own is still telling a European story. Use whatever you like to ground your story, intellectual Canada, but be honest. It is your story - it is not about me". The white writer does not tell a Beothuk story. White writers tell white stories, and they tell stories that serve their desires.

As Keith Winter (1975:40) prefaces a story in his historical account of the last years of the Beothuk: "The details of the story were written down by James Howley, who heard it in 1886 [fifty-seven years after the death of the last Beothuk] from a very old fisherman". And about another "strange, tangled story" Winter notes that "there are at least four different published versions about what happened" and that "many of the details were hotly disputed" (Winter, 1975:45). What we have are sketchy, contradictory narratives constructed by privileged people, abusers, thieves, colonizers, killers, and their descendants about the Beothuk that they did not know and did not have the affection or concern or resources to learn to know. The stories of the Beothuk are not reclaimable. The Beothuk once spoke and sang in their own voices. But they have not spoken for more than 150 years, and they will not speak again. Instead we have the constructed narratives of the descendants of the white European men who exterminated the Beothuk, narratives that are not about the Beothuk or in the voices of the Beothuk or true to the Beothuk, but narratives about the descendants of the white Europeans trying to deal with the guilt of their complicity in the horror of genocide, to explore the heart of darkness that lies at the centre of colonial history, to sing out in new voices convening and echoing and keening the voices of the lost - a kind of mystical and spiritual and otherworldly chorus of voices that refuses to let us sleep peacefully. The Beothuk provide an alphabet of signifying opportunities. There is nobody to interrogate the ways they are re/presented except the people who choose to re/present them. The Beothuk are the silent Other, unattainable, unknown, transcendent, no more than a trace remains. It is easy to mythologize and fictionalize and make them in any image we want - they are a blank and clean slate, a tabula rasa.

More questions: What stories will be written? Who authors? Who has the authority in writing the stories of others? Can I really write the story of others? Or am 
I really always writing my own stories? If I tell a story, am I erasing the stories of others? Who writes who? If I write a story about the Beothuk, does the story also write me? Is there a dialogical writing, revealing, unfolding that goes on? In a strange way do the Beothuk have the opportunity to speak in my writing about them? So the reader who reads these words reads about the Beothuk, at least the reader sees a little of the Beothuk through my eyes, but is this still not one way that the Beothuk have of speaking to others, their voices resurrected in the only way that voices are ever resurrected, in language and the slipping and sliding of language, the unfolding of language, the wild and chaotic oscillation of language? Am I liberating voices or oppressing voices?

\section{Convening a convention of voice(s)}

Our people believe that memory is passed on in more ways than words. We firmly believe that our grandmothers' voices are still alive and in this room, that they are everywhere and the individual can reach back and hear those voices. (Maracle, 1990b:46.)

Writers have to be willing to learn; they have to be open to having certainties shifted, perhaps permanently. They cannot enter as oppressors or even as members of the dominant culture. That sense of humility is what has been sorely lacking in the deluge of justifications that have poured forth in support of the right of the white writer to use any voice. (Philip, 1990: 219.)

To convene is to come together. Jeannette Armstrong (1990a:29) explains her "understanding of how a culture is determined, how culture is passed on. It is through words, it is through the ability to communicate to another person, to communicate to your children the thinking of your people in the past, their history, that you are a people". Armstrong (1990a:29) also contends that "everything we say affects someone, someone is hearing it, someone is understanding it, someone is going to take it and it becomes memory. We are all powerful, each one of us individually. We are able to make things change, to make things happen differently. We are all able to heal". I am encouraged by these words because I think that they suggest that there is room for cooperation and collaboration and inclusion in word-making and story-making, instead of exclusion and isolation and confrontation. Telling the stories of the Beothuk is important for the oppressors so that the oppressors do not forget their history of oppression. To story is to store memory.

So, while I sympathize with Betsy Warland's (1990:34) conviction "that language is ... a value system created and maintained by patriarchal, White, middle-class, heterosexual, educated people who generally tyrannize the rest of the world", I also realize that I am one of those people, as are the writers who have written 
about the Beothuk. While recognizing that writing is always ethical, political, prescriptive, value-laden, powerful, and scandalous, I still contend that more writing, not silence, is the only way to interrogate and undo the tyrannical effects of oppressive language use. We have failed to learn from Native peoples, but I think that is what some of the writers writing stories about the Beothuk are trying to do; they are listening to the Beothuk and seeking to learn from them. The real danger is that we will continue to create the Other in our image only and hear only what we want to hear. The real danger is that we might destroy/erase the Beothuk every time we write about them. Should we leave them in peace? Is it ever possible to write from a culture that is not our own? Do I not always write from my own culture(s) - the bacteria of values invisible but invidious? Perhaps the main reason for writing about the Beothuk is to assure that the memory of them is not lost, or at least the memory of their genocide, the wanton and cruel destruction of a people who called themselves the People, a symbol for other peoples who have been destroyed, past and present. The writers writing about the Beothuk are seeking to know the unknowable. The Beothuk cannot tell their own stories, but they continue to live in the stories of contemporary writers who are seeking to cross the barrier of silence to greater understanding. The Beothuk have been erased, but the memories of the Beothuk have not been erased. In the re/writing of contemporary writers the Beothuk continue to speak. We cannot silence anyone. The Beothuk are gone, and their stories exist only in traces, scraps seen through eyes clouded by time and place and shifting ideologies and the complexities of language, and now new stories by others will be told. This is all there is. Of course "every focus excludes" (Clifford 1992:97), but instead of excluding focuses writers need to focus on their focuses, a self-reflexive focusing on the focus.

The Beothuk will always be silent. They will always be the object of another's description and narration. They will always remain marginalized, oppressed, victimized, subordinate. The Beothuk will never be the subject of their story-making. They will never speak or sing or write in their voices of resistance and opposition and challenge. They will never reclaim their identities or reconstruct their memories or reaffirm their understanding as the Beothuk, the People.

Therefore, the author of a narrative about the Beothuk has a peculiar authority because the object of the narrative is lost and silent and cannot interrogate or contest the narratives writtten and told about them. The author of a narrative about the Beothuk can be caught in a hermetic hermeneutic circle where he or she can write anything without the challenge of dialogue, but I like the advice of Joy Kogawa, the Japanese-Canadian writer who intimately knows the experiences of oppression and exclusion and silence: 
What matters is that you listen to the voice that calls you, whether it comes from the bottom of the well, or whether it comes from the distant stars, whether it comes from your community, whether it comes from within your own heart, whether it comes from your neighbour or from your mate, or whomever it comes from, your calling is to respond to the voice that calls you. Fundamentally, that response is the response of love, so that the writer's role is no different than any other human being's role, which is fundamentally to love and to respond to the voice that cries out to you. (Kogawa, 1990:96-97.)

The author of a narrative about the Beothuk is confronted with the challenge to deconstruct the binarism of subject and object. Is there another option? Can an author enter sympathetically into the world of the object so that his or her narrative speaks in voices that convene the voices of the Other, the object, the written about? Can contemporary writers of stories about the Beothuk seek to respond to voices that they hear, seek to convene the voices of the past and present?

I agree with Lenore Keeshig-Tobias (1990:175) that "literature about Native people by non-Natives is not Native literature", but I am reluctant to support her view that "all white supporters of Native causes will have to step back in the true spirit of respect for self-determination and equality, and let the real Native voices be heard" (Keeshig-Tobias, 1990:177), or at least I am reluctant to promote the silence of any voices. Non-native writers can tell any stories they want to tell, but of course their stories will never be the stories of Native writers.

Needed is a keen appreciation for the way that texts construct knowledge. I am particularly impressed by Marlene Nourbese Philip's (1990:218) advice:

Writers coming from a culture that has a history of oppressing the one they wish to write about would do well to examine their motives. Is their interest a continuance of the tradition of oppression, if only by seeing these cultures as different or exotic, as Other? Does their interest come out of the belief that their own cultural raw material is washed up, that just about anything from the Third World is bound to garner more attention? Is it perhaps the outcome of guilt and a desire to make recompense? Such writers have to examine whether they can write without perpetuating stereotypes.

\section{Interrogating narrative voice(s)}

Characters in fiction are not real people any more than photographs are real people. A believable or authentic character is a plausible composition made out of words. (Rule, 1990:228.) 
All central human relations are, in this widest sense, political, and significant fictional re-presentation of relations among people rearticulates our political relationships. (Suvin, 1988:690.)

Is not any writer (even the pure lyricist) always a 'dramaturge' in the sense that he directs all words to others' voices, including to the image of the author (and to other authorial masks)? (Bakhtin, 1986:110.)

To insist that textuality is all and that the play of the signifier usurps the recreative illusion of character is to turn back at the threshold of interpretation, stopping our ears to both lyric cries and historical imperatives, and from our studious cells overhearing nothing. (Tucker, 1985:243.)

A story is a sequence of events, and discourse is the way the story is told. Narrative voice is then an element of discourse, a means of mediating the textual construction of the story. Narrative voice has rhetorical and ideological and emotional and cognitive ramifications. The discursive machinery of the text is fuelled by the voice which focalizes the perceptions and understanding. The voice seeks to convince the reader, to draw the reader in, to create a sense of reality and an illusion of presence. So a narrative text is a network of signs and signifying practices. I do not want to suggest that a narrative text has some kind of ethical or spiritual or mystical or moral qualities that transcend the rhetoric of language. I certainly do not want to suggest that a narrative about the Beothuk will burst like spontaneous combustion into the fire of an other worldly, even supernatural, identity. When I read a narrative, I perceive the author and the reader and the text as part of a language-constructed and language-mediated enterprise which ought to be assessed and evaluated according to the criteria for textual effectiveness.

And from this perspective of narrative as rhetoric and text, I read the contemporary narratives which seek to re/present the Beothuk, and in reading them I discover that the narratives which play most with rhetorical strategies are the narratives which also open up the most inviting spaces for the convening of voices in communion and humility and affection.

And paradoxically the most reliable narrators in contemporary accounts of the Beothuk are those that Shlomith Rimmon-Kenan calls the unreliable narrators. According to Rimmon-Kenan (1983:100) "a reliable narrator is one whose rendering of the story and commentary on it the reader is supposed to take as an authoritative account of the fictional truth. An unreliable narrator, on the other hand, is one whose rendering of the story and/or commentary on it the reader has reasons to suspect". The reader alvays has reasons to suspect the "rendering of the story and/or commentary on it" when reading narratives about the Beothuk because knowledge of the Beothuk is limited and problematic, traversed by a collective sense of guilt and complicity. Reading contemporary tales of the 
Beothuk necessitates a deconstructive stance that interrogates the narrative voice by assuming that the voice is unreliable and by seeking the gaps and fissures where the voice manifests its textual duplicity.

By deconstructively reading contemporary fictional and poetic narratives which seek to re/present the Beothuk, I perceive several degrees of unreliability in the narrative voices. In Legends of a Lost Tribe: Folk Tales of the Beothuck Indians of Newfoundland (1976) Paul O'Neill clearly states his objectives. He notes that Shanadithit "never had the opportunity to tell the legends of her lost tribe. If she had, she might have told tales like those which the author has created" (O'Neill, 1976:9). He adds: "The stories exist ... only through the imagination of the author, who has carefully interwoven them with what is known of Beothuck life and beliefs" (O'Neill, 1976:10).

How do we know the Other? If I know the rituals and activities and daily lived experiences of another, do I know the Other? Is O'Neill just putting words in the mouths of others? Or is he creating sites for multiple dialogues about the experiences of others? If life is really fiction, isn't O'Neill's book one more person's effort to fictionalize, to make, to recreate, to recover? So what if the tales are not 'true'?

The first narrative account of the Beothuk I ever read was O'Neill's Legends of a Lost Tribe. I was in my early twenties, and I remember being moved by the stories. I think we need lots and lots of people to write lots and lots of stories about themselves and about their relations and perceptions of other people. But the narrative voice of O'Neill's book of tales suggests the representation of Native people which is reproduced and over-determined in North American popular culture, what Keeshig-Tobias (1990:175) calls "the noble and poetic Native voice". By perpetuating this representation O'Neill is not writing in a voice that presents the Beothuk in affirmative or affirming ways - he is simply supporting stereotypes. This raises questions about how the Beothuk and white people are constructed and construed - questions like: What is authenticity? truth? history? fact? fiction? autobiography?

I listen carefully to Lenore Keeshig-Tobias (1990:174) who observes:

It seems a host of non-Native professionals (publishers, editors, producers, directors, and the like) have taken over the work of the missionary and the Indian agent. Like their predecessors, they now know best how to present the Native image, the Native perspective, never dreaming, of course, that it is really their own perspective. And so a few canoes, beads, beaver ponds, and a buffalo or two are used to prop up the whore, the drunkard or the shaman. These romantic cliches and stereotypes, however, serve only to illustrate how they, the outsiders, see or want to see Native peoples. 
This same complaint can be made about Donald Gale's Sooshewan: Child of the Beothuk (1988). Intended for the young reader the story presents a young Beothuk woman who hstens to the voice of her dying grandmother in a dream and defies the advice of her family in order to obey her grandmother's instruction. The story is about courage and love and growing up and resilience and industry in the face of unspeakable hardships. Sooshewan is virtuous in the way of children construed in the image of adults. For example, Sooshewan is very hungry, but offers her dying grandmother some of her small portion of dried egg and fat mixture. When the grandmother refuses, "Shooshewan was glad that she would not have to share her food. Immediately she was ashamed of her thought" (n.p.). Later Sooshewan calls herself a "selfish girl" because she is despairing about being lost in the woods in her efforts to locate her father, "thinking of myself when my father needs help" (n.p.). Sooshewan: Child of the Beothuk is an adventure tale like many adventure tales, but in what ways is the story about the Beothuk? What do I read in this story that informs or extends my understanding of the people that are re/presented? What are the images of the Beothuk revealed in this story? There are many transliterated Beothuk words with their English equivalents provided in context. The foods and the climate and the nomadic lifestyle all seem historically authentic renderings of the Beothuk way of life. But as in O'Neill's Legends of a Lost Tribe the story rings with "the noble and poetic Native voice" (Keeshig-Tobias, 1990:175). The grandmother is ill, and says, "I am old and will die soon, perhaps even before the sun warms the earth again". Her advice to her granddaughter includes: "When I was young, I was frightened of death but now I welcome it. I have talked with the dead. They are waiting for me. Do not cry for me after I am gone, but give yourself to your people who are living" (n.p.). Sooshewan: Child of the Beothuk is a simple adventure tale that tells the reader little about the Beothuk. The story is a white male contemporary Canadian story with Beothuk props and vocabulary.

Geoffrey Ursell's play The Running of the Deer (1981) is mostly about the European colonizers of Newfoundland and an ill-fated plan to establish a treaty with the Beothuk by offering a reward to the person who delivered a live Beothuk to the governor. The plan was to establish peaceful relations between the European settlers and the Beothuk by using a Beothuk to bring messages of good will from the Europeans to the Beothuk nation. The plan backfired when the settlers tried to capture the Beothuk, fighting erupted, and many people were killed.

There is almost no sense of the Beothuk in the play except as cardboard figures. Lieutenant John Cartwright muses about the Beothuk: "And in time they may become a civilized, Christian people, useful subjects of His Majesty. Although, in truth, I think that we shall gain as much from them as they from us" (Ursell, 1981:25). He also notes that "the natives have a natural right to this island, and every invasion of natural right is a violation of the principle of justice. They used 
this land, used all of it until we forced them into the interior. We are the usurpers here" (Ursell, 1981:29). In a similar way another character, Jane Scutt, echoes the view of the guilt-ridden white European: "If these savages, as you choose to call them, do not know the arts and sciences that dignify humanity, at least they are ignorant as well of the vices and enormous crimes which debase mankind!" (Ursell, 1981:32.) Essentially the play represents and reinforces the stereotype of the noble savage. As Gayatri Spivak (1988:292) reminds us, "the question is how to keep the ethnocentric Subject from establishing itself by selectively defining the Other".

Sid Stephen in Beothuck Poems (1976) accomplishes a richer re-telling of the narratives of the Beothuk. In "White Settlements" he writes about how "the paranoia of/civilization/becomes rooted in the land/like a myth," and in "Shawnadithit," he acknowledges that "The meaning of the name/is lost," but he also contends that "True history: ... /does not die with language, lives/in the sound of words/whose meaning/is forgotten". I am intrigued with the paradox of Stephen's lines: perhaps true history resides not in the understanding but in the recognition that understanding is not even possible anymore. Similarly in "She Says Goodbye to Mr. Cormack" Stephen writes: "So much is left unsaid: words/ leave so little/to the imagination" and "her tongue/is even now becoming/stone, / dense with silence/and hard with meaning." Stephen pursues this paradoxical reflection through many of the poems in his sequence. About the death of Shawnadithit in "She Dies in St. John's" he declares that "the arc of her people/ ends/in a small stone house/above the harbour," and that "the story will be whispered/but not told," but he also observes that "Graves outlive/all our other monuments/because/they represent/more guilt than pride," and therefore "Her space inside the earth/will be lost,/will be found to be/all/there is to be".

This same concern for the memory of the Beothuk motivated Peter Such to write Riverrun (1973:ix): "It is tempting to explain my obsession with writing about the Beothuk. Let me just say it is a kind of debt I owe to Nonosabasut, Demasduit, Shawnadithit, Doodebewshet and Longnon - to whom I was introduced first through the pages of history - and to Osnahanut and the other persons in this book whom I met in dreams".

Riverrun recounts the last few years of the Beothuk. In one episode a band of whitemen led by John Peyton has kidnapped Demasduit. Her partner Nonosabasut plans for her release. Such's account of the event unfolds in a rhetorical juxtaposition of two kinds of text (represented in two different fonts) - a speech by Nonosabasut, written by Such in English as a creative rendition of what Nonosabasut might have said (of course none of the whitemen knew the Beothuk language and there is no record of Nonosabasut's speech) and a historical record of the event as recorded by the captors (this record has at least four extant 
versions, but Such's version is frequently referred to in various sources). The following excerpt suggests the tenor of the narrative:

All the People gather together. Nonosabasut tells them-Maybe the whitemen are frightened because we seem to be so many. Maybe they think there are more of us ready to ambush them. Maybe that's why they've taken Demasduit with them, as a hostage. I will go to speak to them by myself. I'll tell them how the People want to make peace with the whitemen as the Micmacs have done. I'll tell them how we shall be friends with them and will share our lands with them in peace. One of you bring me a fresh sprucebough as a token....

The ill fated husband of Mary March, our captive, advanced with a branch of a fir tree (spruce) in his hand. When about ten yards off he stopped and made a long oration. He spoke at least ten minutes; towards the last his gesture became very animated and his eye 'shot fire.' He concluded very mildly, and advancing, shook hands with many of the party - then he attempted to take his wife from us; being opposed ... he became infuriated, and rushing towards her he strove to drag her from them; one of the men rushed forward and stabbed him in the back with a bayonet; turning round, at a blow he laid the fellow at his feet .... Mr - then drew a pistol from his girdle and fired. The poor wretch first staggered then fell on his face: while writhing in agonies, he seemed for a moment to stop; his muscles stiffened; slowly and gradually he raised himself from the ice, turned round, and with a wild gaze surveyed us all in a circle around him. (Such, 1973:80-81.)

None of these words were written or spoken by a Beothuk. There are no records of the Beothuk version of this historical event. Such has constructed this scene out of his own imaginative recounting and out of historical accounts written by the captors with their own vested interests in presenting the events from self-protective perspectives. Such uses a stereotypical kind of prose to narrate part of the story through the focalization of a Beothuk person. This kind of simplified or pared down prose is all too familiar from the popular culture as the way that $\mathrm{Na}$ tive peoples speak. This prose is an imaginative construction only. But what I like about Such's novel is that he presents a complex and multivalent narrative voice with multiple perspectives and challenges to the reliability of the narrators. The reader is invited into the complex web of the story through the complex discursive operations.

In a similar way Kevin Major uses narrative voices in Blood Red Ochre. The novel is a fantasy which plays with connections between the present and the past. The novel unfolds in multiple sections, each labelled with the name of David or Dauoodaset and once with the name Shawnadithit. David and Dauoodaset live in different worlds - David in a contemporary Newfoundland town and Dauoodaset on a nearby island caught in a kind of time warp. David, a young Newfound- 
lander, is falling in love with Nancy, a young woman who has just mysteriously begun going to David's school while Dauoodaset, a young Beothuk, is seeking Shanawdithit who is really Nancy. Meanwhile Nancy/Shanawdithit is showing romantic interest in David, but her motive is to get David's help to return to the island where Daudoodaset is waiting for her. In the end David knows the pain that the Beothuk have known, and he knows the complicity of his people in the destruction of the Beothuk: "He thought of all that had happened. Most of all he thought of Shanawdithit and how she was the last of her people" (Major, 1989: 146). The story is bizarre, and because Major is an accomplished writer, the story is presented in a way that gains and sustains interest. My biggest complaint is that the tone of the sections devoted to Daudoodaset is the same tone used in Such's novel: a kind of primitive and noble voice that is too predictable as the white writer's version of the native voice. A brief excerpt suggests the predictable tone:

It is winter still. Seven of our people came many days over land from the great lake. We wait in this place by the river until the ice melts into pieces to run down to the saltwater. We will go with the running water to find salmon and the beaches heavy with mussels at the drawing down of the tide. There will be seals thick with fat and many seabirds for our arrows. We will not hunger. Spring will be a new life for our people. (Major, 1989:11.)

But the richness of the novel is in the complexity of the narrative. There is juxtaposition of voices as well as an air of mystery and fantasy that prevents the reader too easily entering into the story as a transparent version of reality. The story invites the willing suspension of belief as well as the willing interrogation of truths as they are constructed in the narrative.

\section{Conclusion}

The narrator of Riverrun ends his story with a lament for Shawnadithit "who was left behind with no one to sing for her at the hour of her own death, who went unremembered, the last of the People in the whole high land of the long lakes and the speaking rivers that run to the sea forever, bearing no longer the living People through the frogback rapids, bearing only the dead leaves of the woods in autumn" (Such, 1973:144). In the title of this essay I ask, "Who speaks for extinct nations?" In conclusion I answer, "Nobody and everybody."

\section{Works cited}

Armstrong, J. 1990a. Panel One: Audience Discussion. In: Lee, S., Maracle, L., Marlatt, D. \& Warland, B. Telling It: Women and Language across Cultures. Vancouver: Press Gang Publishers. p. 43-53. 
Armstrong, J. 1990b. Words. In: Lee, S., Maracle, L., Marlatt, D. \& Warland, B. Telling It: Women and Language across Cultures. Vancouver: Press Gang Publishers. p. 2329.

Bakhtin, M. 1986. Speech Genres and Other Late Essays. Trans. Vern. W. McGee. Ed. Caryl Emerson and Michael Holquist. Austin: $U$ of Texas $P$.

Cameron, A. 1990. The Operative Principle Is Trust. In: Scheier, L,. Sheard, S. \& Wachtel, E. (eds.) Language in Her Eye: Views on Writing and Gender by Canadian Women Writing in English. Toronto : Coach House Press. p. 63-71.

Clifford, J. 1992. Traveling Cultures. In: Grossberg, L., Nelson, C. \& Treichier, P. (eds.) Cultural Studies. New York: Routledge. p. 96-116.

Finke, L.A. 1992. Feminist Theory, Women's Writing. Ithaca : Cornell UP.

Gale, D. 1988. Sooshewan: Child of the Beothuk. Illustrated by Shawn Steffler. St. John's : Breakwater Books.

Kogawa, J. 1990. From the Bottom of the Well, from the Distant Stars. In: Lee, S., Maracle, L., Marlatt, D., \& Warland, B. Telling It: Women and Language across Cultures. Vancouver : Press Gang Publishers. p. 95-97.

Keeshig-Tobias, L. 1990. The Magic of Others. In: Scheier, L. Sheard, S. \& Wachtel, E. (eds.) Language in Her Eye: Views on Writing and Gender by Canadian Women Writing in English. Toronto : Coach House Press. p. 173-177.

Lee, S., Maracle L., Marlatt D. \& Warland, B. (eds.) 1990. Telling It: Women and Language Across Cultures. Vancouver : Press Gang Publishers.

Major, K. Blood Red Ochre. 1989. New York: Delacorte Press.

Maracle, L. 1990a. Native Myths: Trickster Alive and Crowing. In: Scheier, L Sheard, S. \& Wachtel, E. Telling It: Women and Language across Cultures. Vancouver : Press Gang Publishers. p. 182-187.

Maracle, L. 1990b. Panel One: Audience Discussion. In: Lee, S., Maracle, L., Marlatt, D. \& Warland, B. (eds.) Telling It: Women and Language across Cultures. Vancouver : Press Gang Publishers. p. 43-53.

Marlatt, D. 1990 . Introduction: Meeting on Fractured Margins. In: Lee, S., Maracle, L., Marlatt, D. \& Warland, B. Telling It: Women and Language across Cultures. Vancouver : Press Gang Publishers. p. 9-18.

Marshall, I. 1989. The Beothuk of Newfoundland: A Vanished People. St. John's : Breakwater Books.

Nelson, C. \& Grossberg L. (eds.) 1988. Marxism and the Interpretation of Culture. Urbana : U of Illinois.

O'Neill, P. 1976. Legends of a Lost Tribe: Folk Tales of the Beothuck Indians of Newfoundland. Toronto : McClelland and Stewart.

Philip, M.N. 1990. The Disappearing Debate: Racism and Censorship. In: Scheier, L., Sheard, S. \& Wachtel, E. Language in Her Eye: Views on Writing and Gender by Canadian Women Writing in English. Toronto : Coach House Press. p. 209-219.

Pittman, A. 1978. "Shanadithit." In: Once When I Was Drowning. St. John's : Breakwater Books. p. 43-46.

Rimmon-Kenan, S. 1983. Narrative Fiction: Contemporary Poetics. London: Routledge.

Rule, J. 1990. Deception in Search of the Truth. In: Scheier, L., Sheard, S. \& Wachtel, E. Language in Her Eye: Views on Writing and Gender by Canadian Women Writing in English. Toronto : Coach House Press. p. 225-228.

Scheier, L., Sheard, S. \& Wachtel, E. (eds.) 1990. Language in Her Eye: Views on Writing and Gender by Canadian Women Writing in English. Toronto : Coach House Press. 
Spivak, G.C. 1988. Can the Subaltern Speak? In: Nelson, C. \& Grossberg, L. Marxism and the Interpretation of Culture. Urbana : U of Illinois. p. 271-313.

Stephen, S. 1976. Beothuck Poems. N.p. : Oberon Press.

Such, P. Riverrun. Toronto : Clarke, Irwin.

Suvin, D. Can People Be (Re)Presented in Fiction?: Toward a Theory of Narrative Agents and a Materialist Critique beyond Technology or Reductionism. In: Nelson, C. \& Grossberg, L. Marxism and the Interpretation of Culture. Urbana : U of Illinois. p. 663-696.

Tucker, H.F. 1985. Dramatic Monologue and the Overhearing of Lyric. In: Hosek, C. \& Parker, P. (eds.) Lyric Poetry: Beyond New Criticism. Ithaca : Comell UP. p. 226-243.

Ursell, G. 1981. The Running of the Deer. Toronto : Playwrights Canada.

Warland, B. 1990 . f.) is sure. In: Lee, S., Maracle, D., Marlatt, D. \& Warland, B. Telling It: Women and Language across Cultures. Vancouver : Press Gang Publishers. p. 31 36.

Winter, K. 1975. Shananditti: The Last of the Beothucks. North Vancouver : J.J. Douglas. 
